Check for updates

Cite this: RSC Adv., 2020, 10, 9955

Received 6th February 2020

Accepted 3rd March 2020

DOI: 10.1039/dOra01152e

rsc.li/rsc-advances

\section{An umpolung reaction of $\alpha$-iminothioesters possessing a cyclopropyl group $\uparrow$}

\author{
Makoto Shimizu, (D) *ab Takayoshi Morimoto, ${ }^{\mathrm{b}}$ Yusuke Yanagi, ${ }^{\mathrm{b}}$ Isao Mizotab \\ and Yusong Zhu iD a
}

An umpolung $N$-alkylation reaction of $\alpha$-cyclopropyl $\alpha$-iminothioesters with diethylaluminum chloride or ethylmagnesium bromide affords the corresponding $N$-ethylated $\alpha$-aminothioesters in good yields. Subsequent oxidation and reaction of the $N$-ethylated product with a thiolate or a chloride anion proceed effectively to give the ring-opened products in good yields. In contrast, relatively "hard" nucleophiles did not give the ring-opened products but gave the addition products to the iminium carbon.

\section{Introduction}

The unique properties of cyclopropyl moieties offer various useful reactions in many organic transformations. ${ }^{1}$ Among them, cyclopropane ring-opening reactions have received considerable attention as a useful carbon chain elongation reaction, since strain-release ring opening of cyclopropanes gives rise to highly functionalized products. ${ }^{2}$ On the other hand, we have been interested in the umpolung reactivity of $\alpha$-iminoesters and have already disclosed several useful reactions (Scheme 1). ${ }^{3}$ Furthermore, upon the oxidation of an intermediary $\alpha$-aminoester enolate derived from $N$-alkylation of $\alpha$-iminoester, many nucleophiles can add to the resulting iminium salt, giving $N, C$-double addition products. When $\alpha, \beta$-unsaturated $\alpha$-iminoesters such as $\alpha$-alkynyl or $\alpha$-alkenyl derivatives were used as substrates, tandem $N$-alkylation- $\gamma$-acylation or

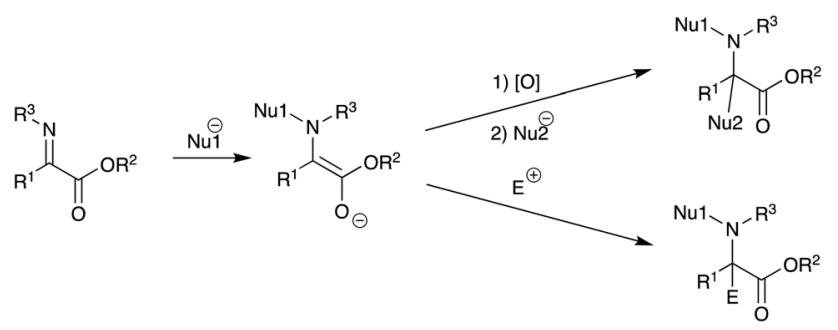

Scheme 1 Tandem reaction of $\alpha$-iminoesters.

${ }^{a}$ School of Energy Science and Engineering, Nanjing Tech University, Nanjing 211816, Jiangsu Province, China

${ }^{b}$ Department of Chemistry for Materials, Graduate School of Engineering, Mie University, Tsu, Mie 514-8507, Japan. E-mail: mshimizu@chem.mie-u.ac.jp

$\dagger$ Electronic supplementary information (ESI) available. See DOI: 10.1039/d0ra01152e vinylogous aldol reaction respectively proceeded in a regioselective manner. ${ }^{4}$ Along this line $\alpha$-cyclopropyl $\alpha$-imino(thio) esters 1 have intrigued us in particular regarding the cyclopropane ring-opening reaction of the $\alpha$-cyclopropyl iminium ion intermediate (Scheme 2).

We have now found that $\alpha$-cyclopropyl $\alpha$-iminothioesters $\mathbf{1}$ are reasonably reactive substrates for the umpolung $N$-alkylation and that the subsequent tandem reaction also proceeds well.
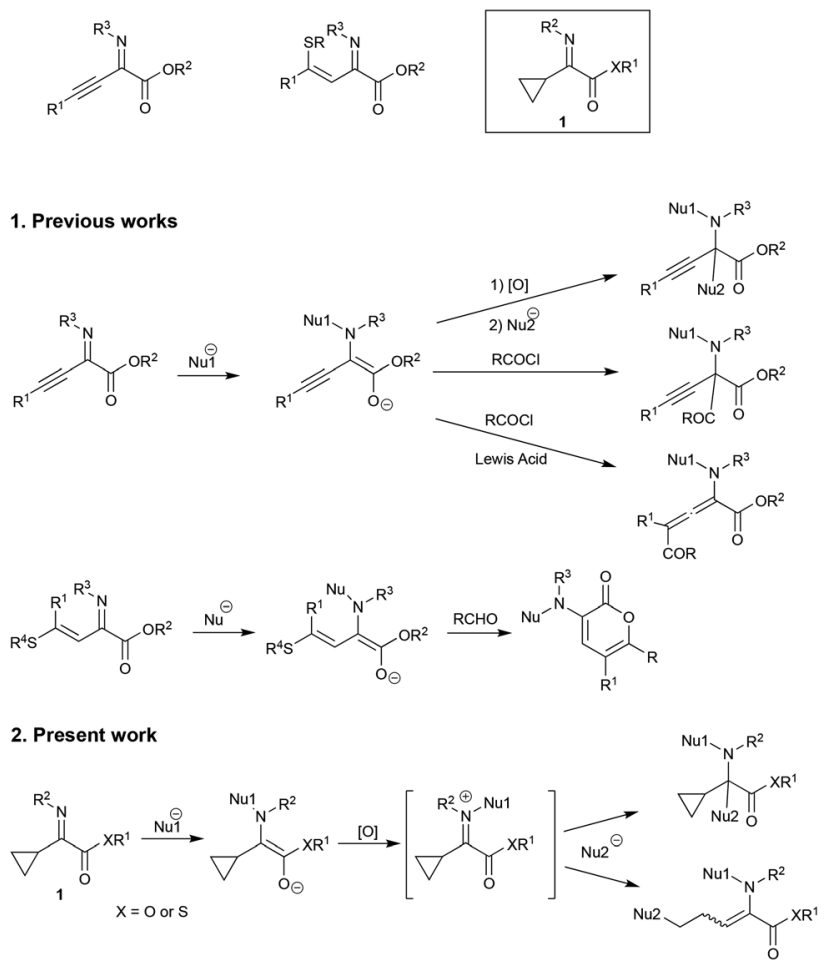

Scheme 2 Previous and present works. 


\section{Results and discussion}

The starting $\alpha$-cyclopropyl $\alpha$-iminoesters and their thioester counterparts 1 were readily prepared according to the reported procedures. ${ }^{5}$ First, the conditions for the ethylation reaction of $\alpha$-cyclopropyl $\alpha$-iminoester $\mathbf{1 b}$ and its thioester counterpart $\mathbf{1 a}$, including the ethylation reagent, solvent, time, and temperature were examined. Table 1 summarizes the results.

Although ethyl Grignard reagent could be used for this reaction, diethylalminum chloride recorded comparable results (entries 3 to 5). Regarding the ester moiety, normal ethyl ester gave a decreased yield of the desired $N$-ethylation product $2 \mathbf{b}$ as compared with the thioester counterpart $2 \mathbf{a}$ (entries 2 and 4). ${ }^{6}$ The best yield was obtained when the reaction was conducted in EtCN for $30 \mathrm{~min}$, and the product 2 a was formed in $90 \%$ yield (entry 8). We next examined the oxidation reaction of an intermediary aluminum enolate species to the iminium salt that could accept the second nucleophile. Table 2 summarizes the results.

Initially, we attempted to determine the amount of the hydrolyzed cyclopropyl ketoester 4. However, this compound was transformed into other derivatives including a cyclopropane ring-opened product, a hydrate, a hydrolyzed acid, and so on under the present oxidation/hydrolysis conditions, and therefore, the yields of stable $N$-ethyl anisidine $\mathbf{3}$ are shown in Table 2. BPO that was effective for the tandem reaction of $\alpha$-aryl $\alpha$-iminoestrers was unsuitable for the present substrate, giving $N$-ethyl anisidine 3 in moderate yields (entries 1 to 3 ). NBS and DBDMH did not efficiently oxidize the present aluminum enolate either (entries 4, 5, and 8), whereas with NCS $N$-ethyl anisidine 3 was obtained in good yield, indicating that NCS is the oxidation reagent of choice for the present substrate (entries 6 and 7). Using NCS as an oxidation reagent for the aluminum enolate, various nucleophiles known as good reagents for conjugate addition reactions were subjected to the present

Table $1 \quad N$-Ethylation of $\alpha$-cycloprpyl $\alpha$-imino(thio)ester

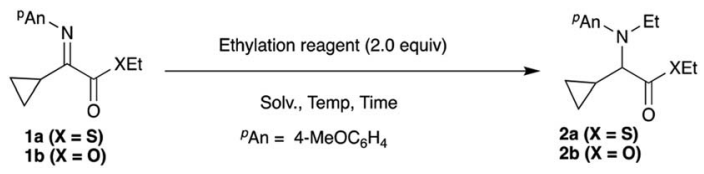

\begin{tabular}{lllllll}
\hline Entry & $\mathrm{X}$ & Reagent & Solv. & Temp. $\left({ }^{\circ} \mathrm{C}\right)$ & Time $(\mathrm{min})$ & 2: yield ${ }^{a}(\%)$ \\
\hline 1 & $\mathrm{O}$ & $\mathrm{Et}_{2} \mathrm{AlCl}$ & $\mathrm{EtCN}$ & -20 to rt & 240 & 53 \\
2 & $\mathrm{O}$ & $\mathrm{Et}_{2} \mathrm{AlCl}$ & $\mathrm{EtCN}$ & -50 to rt & 120 & 41 \\
3 & $\mathrm{~S}$ & $\mathrm{EtMgBr}$ & $\mathrm{EtCN}$ & -50 to rt & 60 & 74 \\
4 & $\mathrm{~S}$ & $\mathrm{Et}_{2} \mathrm{AlCl}$ & $\mathrm{EtCN}$ & -50 to rt & 120 & 75 \\
5 & $\mathrm{~S}$ & $\mathrm{Et}_{2} \mathrm{AlCl}$ & $\mathrm{MeCN}$ & -40 to rt & 120 & 75 \\
6 & $\mathrm{~S}$ & $\mathrm{Et}_{2} \mathrm{AlCl}$ & $\mathrm{CH}_{2} \mathrm{Cl}_{2}$ & -50 to rt & 120 & 61 \\
7 & $\mathrm{~S}$ & $\mathrm{Et}_{2} \mathrm{AlCl}{ }^{b}$ & $\mathrm{EtCN}^{20}$ & -50 to rt & 120 & 68 \\
8 & $\mathrm{~S}$ & $\mathrm{Et}_{2} \mathrm{AlCl}$ & $\mathrm{EtCN}$ & -50 to rt & 30 & 90 \\
9 & $\mathrm{~S}$ & $\mathrm{Et}_{2} \mathrm{AlCl}$ & $\mathrm{EtCN}$ & -50 to rt & 10 & 86 \\
\multicolumn{5}{l}{ Isolated yield. ${ }^{b} \mathrm{Et}_{2} \mathrm{AlCl}(1.5$ equiv.) was used. }
\end{tabular}

Table 2 Oxidation of the intermediary alminum enolate
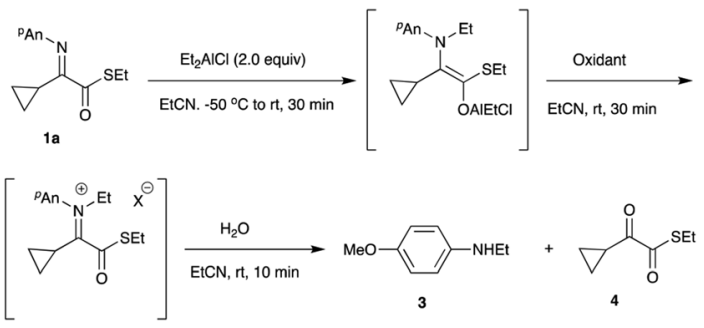

\begin{tabular}{|c|c|c|c|}
\hline Entry & Oxidation reagent ${ }^{a}$ & Equivalent & 3: yield $^{b}(\%)$ \\
\hline 1 & BPO & 1.1 & 40 \\
\hline 2 & $\mathrm{BPO}$ & 1.5 & 34 \\
\hline 3 & BPO & 2.0 & 13 \\
\hline 4 & NBS & 1.1 & 27 \\
\hline 5 & NBS & 2.0 & 26 \\
\hline 6 & NCS & 1.1 & 63 \\
\hline 7 & NCS & 2.0 & 69 \\
\hline 8 & DBDMH & 1.1 & 27 \\
\hline
\end{tabular}

${ }^{a}$ Abbreviations, BPO: benzoyl peroxide, NBS: $N$-bromosuccimide, NCS: $N$-chlorosuccinimide, DBDMH: 1,3-dibromo-5,5-dimethylhydantoin. ${ }^{b}$ Isolated yield.

tandem cyclopropane ring-opening reaction, and scheme 3 summarizes the results.

Diethyl malonate/NaH, $\mathrm{KH}$ or DBU, ethyl acetoacetate/NaH, $\mathrm{KH}$ or $\mathrm{DBU}$, acetylacetone/NaH, $\mathrm{KH}$ or $\mathrm{DBU}, \mathrm{MeNO}_{2} / \mathrm{DBU}$, $\mathrm{EtNO}_{2} / \mathrm{DBU}$, allyltrimethylsilane/TiCl 4 , silyl enol ether/TiCl${ }_{4}$,
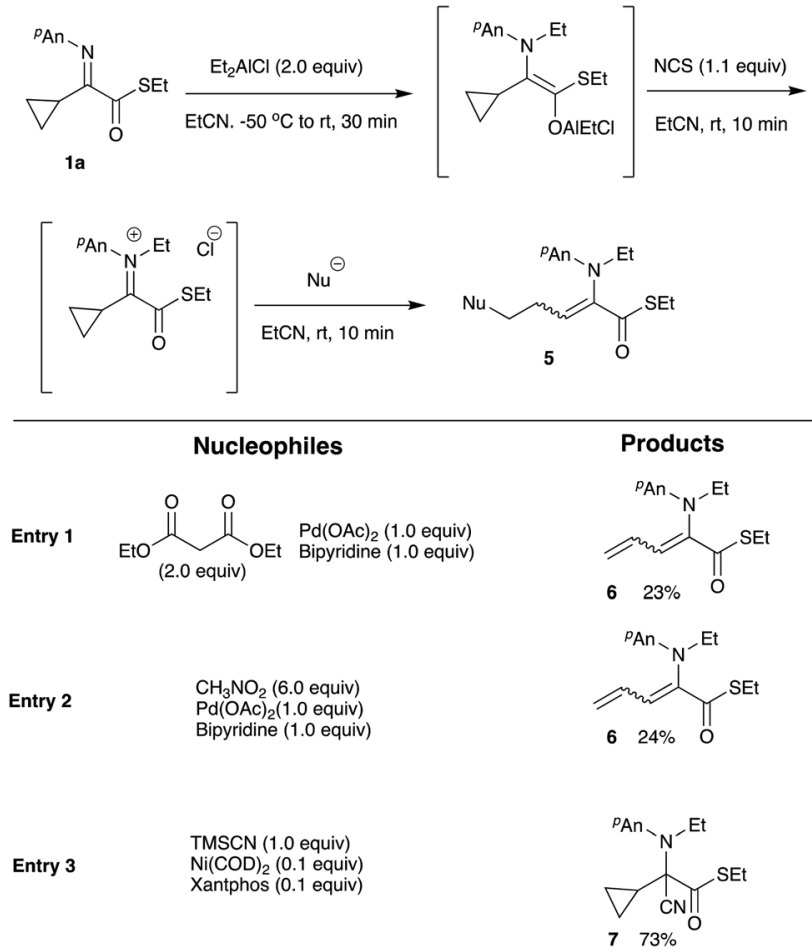

Scheme 3 Attempted cyclopropane ring-opening reaction. 
ketene silyl acetal/ $\mathrm{TiCl}_{4}$, indole, $\mathrm{Bn}_{2} \mathrm{NLi}, \mathrm{Et}_{2} \mathrm{AlCN}, \mathrm{EtMgBr} / \mathrm{CuI}$, EtMgBr/CuCN, $\mathrm{Me}_{2} \mathrm{CuLi}, n \mathrm{Bu}_{2} \mathrm{CuLi} / \mathrm{BF}_{3} \cdot \mathrm{Et}_{2} \mathrm{O}$, and $\mathrm{Et}_{2} \mathrm{CuLi} /$ TMSCl did not give the desired addition/ring-opening product 5, whereas trimethylsilyl cyanide underwent a 1,2-addition reaction to the iminium salt to give the nitrile 7 in $73 \%$ yield (entry 3). Noteworthy is the reaction in the presence of $\mathrm{Pd}(\mathrm{OAc})_{2}$ and bipyridine, giving the ring-opened diene 6 in 23 and 24\% yields, respectively (entries 1 and 2). This kind of diene formation is further examined, and details of this reaction are reported in the latter part of this article. One of the best nucleophiles for conjugate addition is thiolate, ${ }^{7}$ and therefore the use of thiolates was next examined. Table 3 summarizes the results.

The initial ring-opening reaction was carried out with lithium benzenethiolate, and the reaction actually gave the desired ring-opened product $8 \mathbf{a}$ in $23 \%$ yield, indicating that thiolates could be used for the present ring-opening reaction (entry 1). Among the metal thiolates examined, sodium benzenethiolate effected the ring-opening to give the homoallylic sulfide $\mathbf{8 a}$ in $38 \%$ yield (entry 2). Although the reaction with phenythiotrimethylsilane $^{8}$ for $2 \mathrm{~h}$ gave the homoallylic sulfide $8 \mathbf{a}$ in low yield, prolonged reaction times increased the yield to $57 \%$ (entries 3 to 5 ). A better result was obtained when the reaction was carried out with phenylthiotri-butylstannane ${ }^{9}$ for $12 \mathrm{~h}$, and the desired product 8a was obtained in $60 \%$ yield (entry 6). Furthermore, the use of ethylthiotri-butylstannane ${ }^{9}$ recorded the best yield of $79 \%$ (entry 7 ).

We also examined the use of $\alpha$-cyclopropyl $\alpha$-iminoesters $\mathbf{1 b}$ for this type of ring-opening reaction, and Scheme 4 summarizes the representative results.

Although the yields of the desired ring-opened product $8 \mathbf{c}$ were only moderate, the use of BPO together with TMSSPh was found to be crucial for this substrate. A combined use of $\mathrm{Et}_{2} \mathrm{AlCl}$ and $\mathrm{EtAlCl}_{2}$ $(1: 1)$, which was used for the prototype tandem reaction of $\alpha$ phenyl $\alpha$-iminoesters also resulted in a moderate success. ${ }^{3 b}$

In terms of the availability of various alkyl and aryl derivatives, the use of Grignard reagents as the first nucleophile was next examined, and Scheme 5 summarizes the results.

Table 3 Cyclopropane ring-opening reaction with thiolate

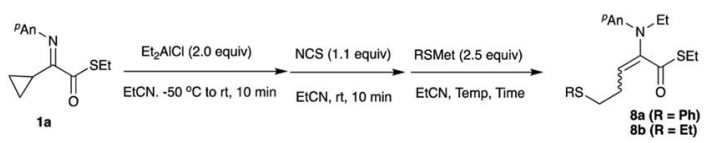

\begin{tabular}{|c|c|c|c|c|c|}
\hline Entry & RSMet & Temp. $\left({ }^{\circ} \mathrm{C}\right)$ & Time (h) & 8: yield $^{a}(\%)$ & $E / Z$ \\
\hline 1 & PhSLi & -50 to $\mathrm{rt}$ & 2 & 23 & $75 / 25$ \\
\hline 2 & $\mathrm{PhSNa}$ & -50 to $\mathrm{rt}$ & 2 & 38 & $86 / 14$ \\
\hline 3 & PhSTMS & $\mathrm{rt}$ & 2 & 16 & $100 / 0$ \\
\hline 4 & PhSTMS & $\mathrm{rt}$ & 12 & 56 & $100 / 0$ \\
\hline 5 & PhSTMS & $\mathrm{rt}$ & 64 & 57 & $100 / 0$ \\
\hline 6 & $\mathrm{PhSSnBu}_{3}$ & $\mathrm{rt}$ & 12 & 60 & $100 / 0$ \\
\hline 7 & $\mathrm{EtSSnBu}_{3}$ & $\mathrm{rt}$ & 13 & 79 & $98 / 2$ \\
\hline
\end{tabular}

${ }^{a}$ Isolated yield.

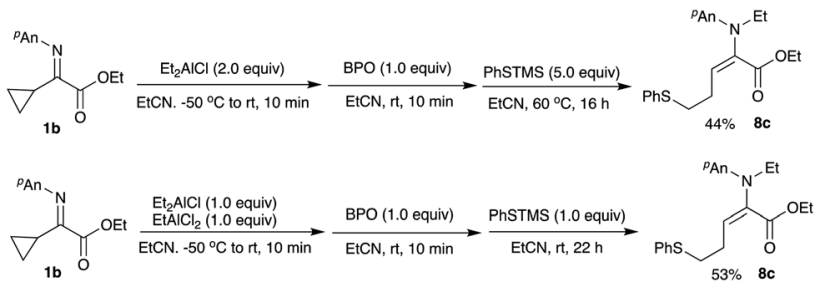

Scheme 4 Ring-opening reaction of $\alpha$-cyclopropyl $\alpha$-iminoester $1 \mathrm{~b}$.

Although the first $N$-alkylation proceeded relatively well (see, Table 1, entry 3), the subsequent oxidation/second nucleophilic addition did not give the desired products in good yields. Therefore, aluminum reagents appear to be the reagent of choice for the present tandem reaction.

As mentioned earlier (Scheme 3, entries 1 and 2), an intriguing ring-opening reaction was observed after the oxidation of the intermediary aluminum enolate with NCS. Scheme 6 summarizes the results of ring opening-chlorination and/or diene formation.

After oxidation of the aluminum enolate with NCS the reaction mixture was allowed to stand with $\mathrm{Ti}(\mathrm{OEt})_{4}$ at room temperature for $72 \mathrm{~h}$ to give the ring-opened/chlorinated product 9 in 55\% yield, indicating that the chloride anion formed during the oxidation could attack the cyclopropane ring to open it. Regarding the diene formation, we screened several conditions and found that in the presence of triethylamine or triethylamine/silica gel the elimination of hydrogen chloride proceeded to give the diene 6 in $44 \%$ or $58 \%$, respectively.

Moreover, we observed that the use of relatively "hard" nucleophiles such as metal cyanide led to the $C$-addition reaction of the iminium carbon instead of the ring-opening reaction (for example see, Scheme 3, entry 3 and Scheme 5). Other representative results of this type of 1,2-addition reaction are shown in Scheme 7.

As shown in Scheme 7 this iminium salt is a relatively reactive species for the nucleophiles. Both TMSCN and acetone cyanohydrin underwent a cyanation reaction to give the aminonitrile 7 in $89 \%$ and $88 \%$, respectively. Regarding the $\alpha$ cyclopropyl $\alpha$-iminoester $\mathbf{1 b}, N$-ethylation/ $C$-allylation reaction proceeded to give the double addition product 10 in $50 \%$ yield.

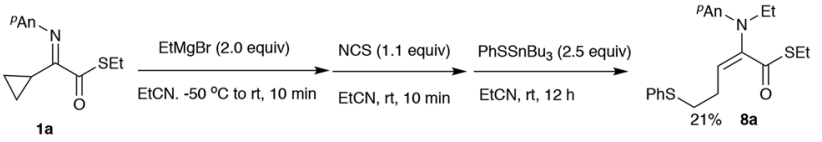

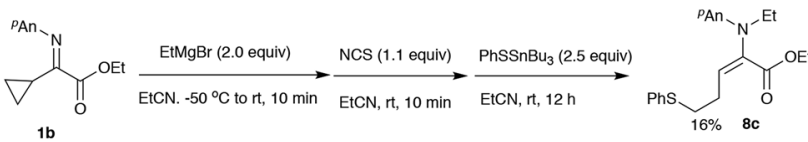

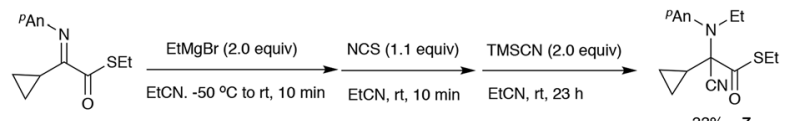

$$
\begin{aligned}
& 1 a \\
& \text { 33\% } 7
\end{aligned}
$$

Scheme 5 Attempted use of Grignard reagent for the tandem reaction. 


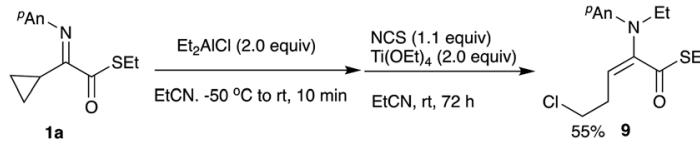

$$
\text { 1a }
$$
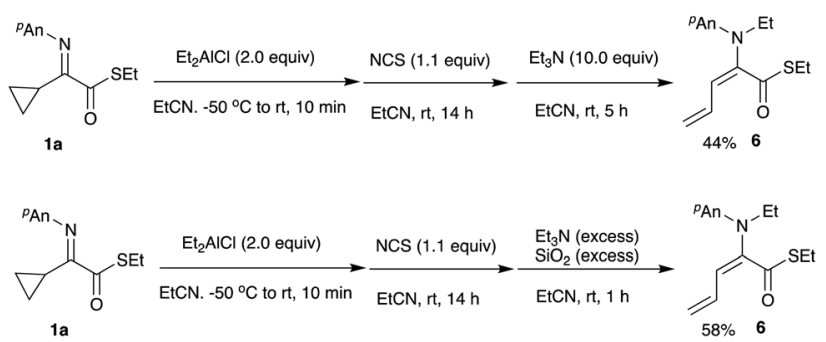

Scheme 6 Ring-opening/chlorination or diene formation.
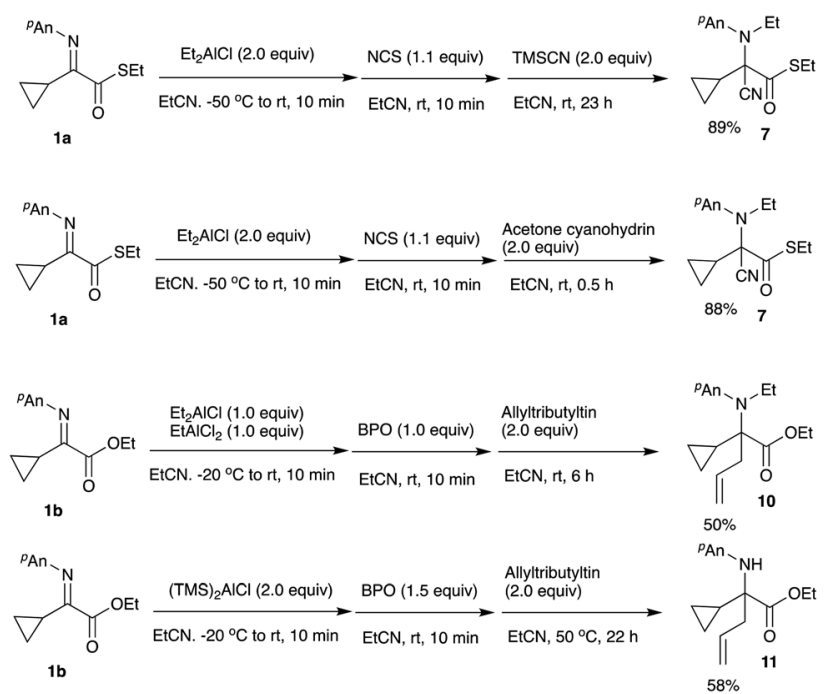

Scheme 7 Tandem N,C-addition to $\alpha$-cyclopropyl $\alpha$-iminoesters $1 \mathrm{a}$, $1 b$.

When (TMS) ${ }_{2} \mathrm{AlCl}^{10}$ was used in place of ethylation reagents, the $C$-allylation product 11 was obtained in 58\% yield after removal of the TMS moiety with aqueous KF. The following Scheme 8 shows the possible reaction pathways.

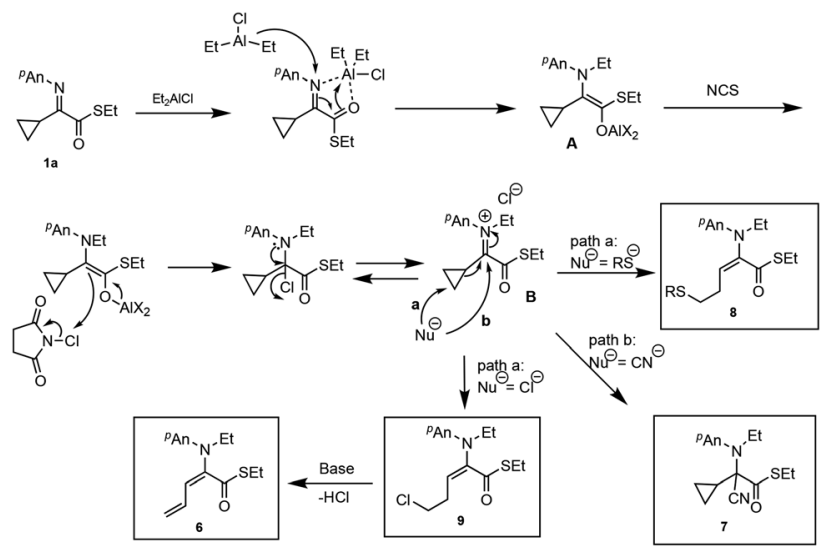

Scheme 8 Proposed reaction pathways.
First, ethylation at the imino nitrogen gives the aluminum enolate $\mathbf{A}$, which in turn is oxidized with NCS to give the iminium salt $\mathbf{B}$. This iminium salt $\mathbf{B}$ undergoes a ring-opening sulfenylation or chlorination reaction to give the homoallylic sulfide 8 or chloride 9, respectively. Treatment of the homoallylic chloride $\mathbf{9}$ with a certain base induces the elimination of $\mathrm{HCl}$ to give the diene $\mathbf{6}$.

\section{Conclusions}

In conclusion, $\alpha$-cyclopropyl $\alpha$-iminothioesters readily underwent the $N$-alkylation reaction with alkylaluminum reagents, giving the corresponding $N$-alkylated products in good yields. Subsequent oxidation/ring-opening of the $N$-alkylated products was conducted with $\mathrm{NCS} / n \mathrm{Bu}_{3} \mathrm{SnSR}$ to produce the homoallylic sulfides in moderate to good yields. Since homoallylic sulfides are useful compounds for further functional group interconversions including a selective $\mathrm{C}-\mathrm{C}$ bond formation, ${ }^{\mathbf{1 1}}$ the present procedure offers a useful addition to the existing methodologies. We also found an intriguing homoallylic chloride formation induced by the formed chloride anion during the oxidation of the intermediate aluminum enolate with NCS. Tandem $N, C$-addition was also found using relatively "hard" second nucleophiles.

\section{Experimental}

\section{General aspects}

Infrared spectra were determined on a JASCO FT/IR-460 plus spectrometer. ${ }^{1} \mathrm{H}$ NMR and ${ }^{13} \mathrm{C}$ NMR spectra were recorded with a JEOL ECX-400P, or a JEOL A-500 spectrometer using tetramethylsilane as an internal standard. Mass spectra were recorded on a JEOL MS-700D spectrometer. Acetonitrile (MeCN) and propionitrile (EtCN) were distilled from phosphorus pentaoxide and then from calcium hydride, and stored over Molecular Sieves 4A. Diethylether $\left(\mathrm{Et}_{2} \mathrm{O}\right)$ was purified with a Glass Contour Organic Solvent Purification System of Nikko Hansen \& Co., Ltd. Dichloromethane $\left(\mathrm{CH}_{2} \mathrm{Cl}_{2}\right)$ was distilled from calcium hydride and stored over molecular sieves $4 \AA$ A. $S$-Ethyl 2-cyclopropyl-2-[(4methoxyphenyl)imino]ethanethioate $\mathbf{1 a}^{3 \boldsymbol{e}, 5}$ and ethyl 2cyclopropyl[(4-methoxyphenyl)imino]acetate $\mathbf{1 b}^{\mathbf{3 b}}$ were synthesized by the reported procedures. Purification of products was performed by column chromatography on silica gel (Kanto Silica Gel 60N) and/or preparative TLC on silica gel (Merck Kiesel Gel GF254 or Wako Gel B-5F).

\section{Synthesis of $S$-ethyl 2-cyclopropyl-2-[ethyl(4-methoxyphenyl) amino]ethanethioate $2 \mathrm{a}$}

In a $30 \mathrm{~mL}$ two-necked round-bottomed flask equipped with a magnetic stirring bar, a rubber septum, and an argon balloon was placed $S$-ethyl 2-cyclopropyl-2-[(4-methoxyphenyl)imino] ethanethioate $1 \mathrm{a}(39.5 \mathrm{mg}, 0.150 \mathrm{mmol})$ in propionitrile (0.5 $\mathrm{mL})$ at $-50{ }^{\circ} \mathrm{C}$. To it was added $\mathrm{Et}_{2} \mathrm{AlCl}(0.27 \mathrm{~mL}, 0.286 \mathrm{mmol}$, $1.05 \mathrm{M}$ in $n$ hexane). After the mixture was stirred for $30 \mathrm{~min}$ at room temperature, the reaction was quenched with sat. aq. $\mathrm{NaHCO}_{3}(10 \mathrm{~mL})$, and the whole mixture was extracted with 
ethyl acetate $(5 \mathrm{~mL} \times 3)$. The combined extracts were washed with brine $(5 \mathrm{~mL} \times 2)$, dried over anhydrous $\mathrm{Na}_{2} \mathrm{SO}_{4}$, and concentrated in vacuo. The crude product was purified on silica gel TLC (nhexane : ethyl acetate $=6: 1$ ) to give the title compound 2a.

Yield 90\% (39.6 mg); yellow oil; $R_{\mathrm{f}}=0.6$ ( $n$ hexane : ethyl acetate $=6: 1) ;{ }^{1} \mathrm{H}$ NMR $\left(400 \mathrm{MHz}, \mathrm{CDCl}_{3}\right) \delta 0.22-0.29(\mathrm{~m} 1 \mathrm{H})$, 0.45-0.57 (m 2H), 0.69-0.76 (m 1H), 1.14-1.25 (m 1H), 1.17 (dd, $=7.1,7.1 \mathrm{~Hz}, 3 \mathrm{H}), 1.21(\mathrm{dd}, J=7.3,7.3 \mathrm{~Hz}, 3 \mathrm{H}), 2.75-2.88(\mathrm{~m}$ $2 \mathrm{H}), 3.22(\mathrm{~d}, J=9.6 \mathrm{~Hz}, 1 \mathrm{H}), 3.32-3.51(\mathrm{~m} 2 \mathrm{H}), 3.75(\mathrm{~s}, 3 \mathrm{H}), 6.80-$ $6.81(\mathrm{~m}, 4 \mathrm{H}) ;{ }^{13} \mathrm{C} \mathrm{NMR}\left(100 \mathrm{MHz}, \mathrm{CDCl}_{3}\right) \delta 4.2,5.2,12.1,14.6$, 23.0, 42.8, 55.5, 114.4, 118.2, 142.1, 153.1, 203.4; IR (neat) 2970, 2931, 2833, 1684, 1511, 1244, 1040, 830, 814, 728, $514 \mathrm{~cm}^{-1}$; HRMS (EI) calcd for $\mathrm{C}_{16} \mathrm{H}_{23} \mathrm{NO}_{2} \mathrm{~S}(\mathrm{M})^{+} 293.1450$, found 293.1459.

\section{Synthesis of ethyl 2-cyclopropyl-2-[ethyl(4-methoxyphenyl) amino]acetate $2 b$}

In a $30 \mathrm{~mL}$ two-necked round-bottomed flask equipped with a magnetic stirring bar, a rubber septum, and an argon balloon was placed ethyl 2-cyclopropyl[(4-methoxyphenyl)imino]acetate 1b $(37.1 \mathrm{mg}, 0.150 \mathrm{mmol})$ in propionitrile $(1.5 \mathrm{~mL})$ at $-20^{\circ} \mathrm{C}$. To it was added $\mathrm{Et}_{2} \mathrm{AlCl}(0.15 \mathrm{~mL}, 0.165 \mathrm{mmol}, 1.07 \mathrm{M}$ in $n$ hexane). After the mixture was stirred for $4 \mathrm{~h}$ at room temperature, the reaction was quenched with sat. aq. $\mathrm{NaHCO}_{3}(10 \mathrm{~mL})$, and the whole mixture was extracted with ethyl acetate $(5 \mathrm{~mL} \times 3)$. The combined extracts were washed with brine $(5 \mathrm{~mL} \times 2)$, dried over anhydrous $\mathrm{Na}_{2} \mathrm{SO}_{4}$, and concentrated in vacuo. The crude product was purified on silica gel TLC ( $n$ hexane : ethyl acetate $=$ $6: 1)$ to give the title compound $2 \mathbf{b}$.

Yield 53\% (22.0 mg); yellow oil; $R_{\mathrm{f}}=0.5$ (nhexane : ethyl acetate $=6: 1) ;{ }^{1} \mathrm{H}$ NMR $\left(400 \mathrm{MHz}, \mathrm{CDCl}_{3}\right) \delta 0.32-0.38(\mathrm{~m}, 1 \mathrm{H})$, 0.44-0.50 (m, 1H), 0.58-0.71 (m, 2H), 1.14 (dd, 3H, $J=7.1,7.1$ $\mathrm{Hz}), 1.21(\mathrm{t}, 3 \mathrm{H}, J=7.1 \mathrm{~Hz}), 1.23-1.30(\mathrm{~m}, 1 \mathrm{H}), 3.21(\mathrm{~d}, J=$ $9.6 \mathrm{~Hz}, 1 \mathrm{H}), 3.38-3.57(\mathrm{~m}, 2 \mathrm{H}), 3.74(\mathrm{~s}, 3 \mathrm{H}), 4.13(\mathrm{q}, 2 \mathrm{H}, J=7.1$ $\mathrm{Hz})$, 6.76-6.81 (m, 4H); ${ }^{13} \mathrm{C} \mathrm{NMR}\left(100 \mathrm{MHz}, \mathrm{CDCl}_{3}\right) \delta 4.6,4.8$, 12.4, 14.1, 14.2, 42.6, 55.6, 60.4, 68.9, 114.4, 117.6, 142.7, 152.8, 173.1; IR (neat) 2979, 1732, 1512, 1464, 1370, 1244, 1180, 1038, $815,535 \mathrm{~cm}^{-1}$; HRMS (EI) calcd for $\mathrm{C}_{16} \mathrm{H}_{23} \mathrm{NO}_{2} \mathrm{~S}(\mathrm{M})^{+}$293.1449, found 293.1450 .

\section{Oxidation of the intermediary aluminum enolate to produce $N$-ethylanisidine 3}

In a $30 \mathrm{~mL}$ two-necked round-bottomed flask equipped with a magnetic stirring bar, a rubber septum, and an argon balloon was placed $S$-ethyl 2-cyclopropyl-2-[(4-methoxyphenyl)imino] ethanethioate $1 \mathrm{a}(39.5 \mathrm{mg}, 0.150 \mathrm{mmol})$ in propionitrile $(0.5$ $\mathrm{mL})$ at $-50{ }^{\circ} \mathrm{C}$. To it was added $\mathrm{Et}_{2} \mathrm{AlCl}(0.27 \mathrm{~mL}, 0.286 \mathrm{mmol}$, $1.05 \mathrm{M}$ in $n$ hexane). After the mixture was stirred for $30 \mathrm{~min}$ at room temperature, a solution of NCS $(39.9 \mathrm{mg}, 0.30 \mathrm{mmol})$ in propionitrile $(0.75 \mathrm{~mL})$ was added. The mixture was stirred for $30 \mathrm{~min}$ at room temperature and then quenched with sat. aq. $\mathrm{NaHCO}_{3}(10 \mathrm{~mL})$, and the whole mixture was extracted with ethyl acetate $(5 \mathrm{~mL} \times 3)$. The combined extracts were washed with brine $(5 \mathrm{~mL} \times 2)$, dried over anhydrous $\mathrm{Na}_{2} \mathrm{SO}_{4}$, and concentrated in vacuo. The crude product was purified on silica gel TLC ( $n$ hexane : ethyl acetate $=6: 1$ ) to give $N$-ethylanisidine 3.

Yield 69\% (15.6 mg); yellow oil; $R_{\mathrm{f}}=0.3$ ( $n$ hexane : ethyl acetate $=6: 1) ;{ }^{1} \mathrm{H}$ NMR $\left(400 \mathrm{MHz}, \mathrm{CDCl}_{3}\right) \delta 1.24(\mathrm{t}, J=7.3 \mathrm{~Hz}$, $3 \mathrm{H}), 3.11(\mathrm{q}, J=7.3 \mathrm{~Hz}, 2 \mathrm{H}), 3.74(\mathrm{~s}, 3 \mathrm{H}), 6.59(\mathrm{~d}, J=8.9 \mathrm{~Hz}, 2 \mathrm{H})$, $6.78(\mathrm{~d}, J=8.9 \mathrm{~Hz}, 2 \mathrm{H})$, The $\mathrm{N}-\mathrm{H}$ proton could not be detected; ${ }^{13} \mathrm{C}$ NMR $\left(100 \mathrm{MHz}, \mathrm{CDCl}_{3}\right) \delta 15.0,39.5,55.8,114.1,114.9$, 142.7, 152.1; IR (neat) 2880, 1530, 1260, 1050, $830 \mathrm{~cm}^{-1}$; HRMS (EI) calcd for $\mathrm{C}_{9} \mathrm{H}_{13} \mathrm{NO}\left(\mathrm{M}^{+}\right)$151.0997, found: 151.0981 .

\section{Synthesis of $S$-ethyl (E)-2-(ethyl(4-methoxyphenyl)amino) penta-2,4-dienethioate 6}

In a $30 \mathrm{~mL}$ two-necked round-bottomed flask equipped with a magnetic stirring bar, a rubber septum, and an argon balloon was placed $S$-ethyl 2-cyclopropyl-2-[(4-methoxyphenyl)imino] ethanethioate 1a $(26.8 \mathrm{mg}, 0.10 \mathrm{mmol})$ in propionitrile $(0.5$ $\mathrm{mL})$ at $-50{ }^{\circ} \mathrm{C}$. To it was added $\mathrm{Et}_{2} \mathrm{AlCl}(0.19 \mathrm{~mL}, 0.20 \mathrm{mmol}$, $1.05 \mathrm{M}$ in $n$ hexane). After the mixture was stirred for $10 \mathrm{~min}$ at room temperature, a solution of NCS $(22.0 \mathrm{mg}, 0.15 \mathrm{mmol})$ in propionitrile $(0.75 \mathrm{~mL})$ was added. The mixture was stirred for $14 \mathrm{~h}$ at room temperature and then quenched with sat. aq. $\mathrm{NaHCO}_{3}(10 \mathrm{~mL})$. The whole mixture was extracted with ethyl acetate $(5 \mathrm{~mL} \times 3)$. The combined extracts were washed with brine $(5 \mathrm{~mL} \times 2)$, dried over anhydrous $\mathrm{Na}_{2} \mathrm{SO}_{4}$, and concentrated in vacuo. The crude product was purified on silica gel TLC ( $n$ hexane : ethyl acetate $=6: 1+10 \% \mathrm{Et}_{3} \mathrm{~N}$ ) to give the title compound 9.

Yield 58\% (25.3 mg); reddish oil; $R_{\mathrm{f}}=0.45$ ( $n$ hexane : ethyl acetate $=6: 1) ;{ }^{1} \mathrm{H}$ NMR $\left(400 \mathrm{MHz}, \mathrm{CDCl}_{3}\right) \delta 1.21(\mathrm{t}, J=7.3 \mathrm{~Hz}$, $3 \mathrm{H}), 1.24(\mathrm{t}, J=7.0 \mathrm{~Hz}, 3 \mathrm{H}), 2.88(\mathrm{q}, J=7.3 \mathrm{~Hz}, 2 \mathrm{H}), 3.53(\mathrm{q}, J=$ $7.0 \mathrm{~Hz}, 2 \mathrm{H}), 3.74$ (s, 3H), 5.43 (dd, $J=10.0,1.0 \mathrm{~Hz}, 1 \mathrm{H}), 5.64$ (dd, $J=17.2,1.0 \mathrm{~Hz}, 1 \mathrm{H}), 6.35$ (ddd, $J=17.0,11.0,10.0 \mathrm{~Hz}, 1 \mathrm{H})$, 6.63-6.67 (m, 2H), 6.78-6.82 (m, 2H) $7.13(\mathrm{~d}, J=11.0 \mathrm{~Hz}, 1 \mathrm{H})$; ${ }^{13} \mathrm{C} \mathrm{NMR}\left(100 \mathrm{MHz}, \mathrm{CDCl}_{3}\right) \delta 13.0,14.4,23.4,46.0,55.6,114.2$, 114.7, 126.6, 131.5, 133.8, 140.1, 141.2, 152.2, 194.4; HRMS (EI) calcd for $\mathrm{C}_{16} \mathrm{H}_{21} \mathrm{NO}_{2} \mathrm{~S}(\mathrm{M})^{+}$291.1293, found 291.1299.

\section{Synthesis of $S$-ethyl 2-cyano-2-cyclopropyl-2-[ethyl(4- methoxyphenyl)amino]ethanethioate 7}

In a $30 \mathrm{~mL}$ two-necked round-bottomed flask equipped with a magnetic stirring bar, a rubber septum, and an argon balloon was placed $S$-ethyl 2-cyclopropyl-2-[(4-methoxyphenyl)imino] ethanethioate $1 \mathrm{a}(39.5 \mathrm{mg}, 0.150 \mathrm{mmol})$ in propionitrile $(0.5$ $\mathrm{mL})$ at $-50{ }^{\circ} \mathrm{C}$. To it was added $\mathrm{Et}_{2} \mathrm{AlCl}(0.27 \mathrm{~mL}, 0.286 \mathrm{mmol}$, $1.05 \mathrm{M}$ in $n$ hexane). After the mixture was stirred for $10 \mathrm{~min}$ at room temperature, a solution of NCS $(22.0 \mathrm{mg}, 0.15 \mathrm{mmol})$ in propionitrile $(0.75 \mathrm{~mL})$ was added. The mixture was stirred for $10 \mathrm{~min}$ at room temperature, and TMSCN $(0.04 \mathrm{~mL} 0.30 \mathrm{mmol})$ was added. After the mixture was stirred for $23 \mathrm{~h}$ at room temperature, it was quenched with sat. aq. $\mathrm{NaHCO}_{3}(10 \mathrm{~mL})$, and the whole mixture was extracted with ethyl acetate $(5 \mathrm{~mL} \times$ $3)$. The combined extracts were washed with brine $(5 \mathrm{~mL} \times 2)$, dried over anhydrous $\mathrm{Na}_{2} \mathrm{SO}_{4}$, and concentrated in vacuo. The crude product was purified on silica gel TLC (nhexane : ethyl acetate $=6: 1$ ) to give the title compound 7 . 
Yield $89 \%$ (42.5 mg); yellow oil; $R_{\mathrm{f}}=0.5$ (nhexane : ethyl acetate $=6: 1) ;{ }^{1} \mathrm{H}$ NMR $\left(400 \mathrm{MHz}, \mathrm{CDCl}_{3}\right) \delta 0.06-0.13(\mathrm{~m}, 1 \mathrm{H})$, $0.26-0.33(\mathrm{~m}, 1 \mathrm{H}), 0.39-0.46(\mathrm{~m}, 1 \mathrm{H}), 0.52-0.59(\mathrm{~m}, 1 \mathrm{H}), 0.94(\mathrm{t}, J$ $=7.1 \mathrm{~Hz}, 3 \mathrm{H}), 1.04-1.11(\mathrm{~m}, 1 \mathrm{H}), 1.28(\mathrm{t}, J=7.6 \mathrm{~Hz}, 3 \mathrm{H}), 2.77-$ 2.98 (m, 3H), 3.19-3.27 (m, 1H), 3.80 (s, 3H), 6.83-6.87 (m, 2H), 7.24-7.28 (m, 2H); ${ }^{13} \mathrm{C}$ NMR (100 MHz, $\left.\mathrm{CDCl}_{3}\right) \delta$ 1.7, 5.6, 13.0, $14.4,18.7,23.5,48.3,55.4,79.42,113.9,129.8,136.5,158.4$, 198.8; IR (neat) 2973, 2364, 2332, 1690, 1510, 1244, 1167, 1082, $1038,879,835,547,502 \mathrm{~cm}^{-1}$; HRMS (EI) calcd for $\mathrm{C}_{17} \mathrm{H}_{22} \mathrm{~N}_{2} \mathrm{O}_{2} \mathrm{~S}$ $(\mathrm{M})^{+} 318.1402$, found 318.1402 .

\section{Synthesis of $S$-ethyl (E)-2-[ethyl(4-methoxyphenyl)amino]-5- (phenylthio)pent-2-enethioate 8a}

In a $30 \mathrm{~mL}$ two-necked round-bottomed flask equipped with a magnetic stirring bar, a rubber septum, and an argon balloon was placed $S$-ethyl 2-cyclopropyl-2-[(4-methoxyphenyl)imino] ethanethioate $1 \mathrm{a}(39.5 \mathrm{mg}, 0.150 \mathrm{mmol})$ in propionitrile (0.5 $\mathrm{mL})$ at $-50{ }^{\circ} \mathrm{C}$. To it was added $\mathrm{Et}_{2} \mathrm{AlCl}(0.27 \mathrm{~mL}, 0.286 \mathrm{mmol}$, $1.05 \mathrm{M}$ in $n$ hexane). After the mixture was stirred for $10 \mathrm{~min}$ at room temperature, a solution of NCS $(22.0 \mathrm{mg}, 0.15 \mathrm{mmol})$ in propionitrile $(0.75 \mathrm{~mL})$ was added. The mixture was stirred for $10 \mathrm{~min}$ at room temperature, and a solution of $n \mathrm{Bu}_{3} \mathrm{SnSPh}$ $(119.7 \mathrm{mg}, 0.30 \mathrm{mmol})$ in propionitrile $(1.0 \mathrm{~mL})$ was added. After the mixture was stirred for $64 \mathrm{~h}$ at room temperature, it was quenched with sat. aq. $\mathrm{NaHCO}_{3}(10 \mathrm{~mL})$, and the whole mixture was extracted with ethyl acetate $(5 \mathrm{~mL} \times 3)$. The combined extracts were washed with brine $(5 \mathrm{~mL} \times 2)$, dried over anhydrous $\mathrm{Na}_{2} \mathrm{SO}_{4}$, and concentrated in vacuo. The crude product was purified on silica gel TLC ( $n$ hexane : ethyl acetate $=6: 1$ ) to give the title compound $\mathbf{8 a}$.

Yield $60 \%$ (36.3 mg); yellow oil; $R_{\mathrm{f}}=0.4$ (nhexane : ethyl acetate $=6: 1) ;{ }^{1} \mathrm{H} \mathrm{NMR}\left(400 \mathrm{MHz}, \mathrm{CDCl}_{3}\right) \delta 1.16(\mathrm{t}, J=7.1 \mathrm{~Hz}$, $3 \mathrm{H}), 1.21(\mathrm{t}, J=7.5 \mathrm{~Hz}, 3 \mathrm{H}), 2.32(\mathrm{dt}, J=7.3,7.3 \mathrm{~Hz}, 2 \mathrm{H}), 2.83(\mathrm{q}$, $J=7.5 \mathrm{~Hz}, 2 \mathrm{H}), 2.91(\mathrm{t}, J=7.3 \mathrm{~Hz}, 2 \mathrm{H}), 3.41(\mathrm{q}, J=7.1 \mathrm{~Hz}, 2 \mathrm{H})$, 3.75 (s, 3H), 6.59-6.63 (m, 2H), 6.74-6.81 (m, 3H), 7.13-7.24 (m, $5 \mathrm{H}) ;{ }^{13} \mathrm{C} \mathrm{NMR}\left(100 \mathrm{MHz}, \mathrm{CDCl}_{3}\right) \delta 12.9,14.3,23.4,27.9,31.8$, 45.5, 55.6, 114.2, 114.7, 126.1, 128.9, 129.4, 134.6, 135.5, 140.8, 142.1, 152.2, 193.9; IR (neat) 2932, 1715, 1649, 1510, 1247, 1029, 834, 740, 692, 530, $516 \mathrm{~cm}^{-1}$; HRMS (EI) calcd for $\mathrm{C}_{22} \mathrm{H}_{27} \mathrm{NO}_{2} \mathrm{~S}$ $(\mathrm{M})^{+}$401.1483, found 401.1502 .

\section{Synthesis of $S$-ethyl $(E)-2$-[ethyl(4-methoxyphenyl)amino]-5- (ethylthio)pent-2-enethioate $8 \mathrm{~b}$}

In a $30 \mathrm{~mL}$ two-necked round-bottomed flask equipped with a magnetic stirring bar, a rubber septum, and an argon balloon was placed $S$-ethyl 2-cyclopropyl-2-[(4-methoxyphenyl)imino] ethanethioate $1 \mathrm{a}(39.5 \mathrm{mg}, 0.150 \mathrm{mmol})$ in propionitrile $(0.5$ $\mathrm{mL})$ at $-50{ }^{\circ} \mathrm{C}$. To it was added $\mathrm{Et}_{2} \mathrm{AlCl}(0.27 \mathrm{~mL}, 0.286 \mathrm{mmol}$, $1.05 \mathrm{M}$ in $n$ hexane). After the mixture was stirred for $10 \mathrm{~min}$ at room temperature, a solution of NCS $(22.0 \mathrm{mg}, 0.15 \mathrm{mmol})$ in propionitrile $(0.75 \mathrm{~mL})$ was added. The mixture was stirred for $10 \mathrm{~min}$ at room temperature, and a solution of $n \mathrm{Bu}_{3} \mathrm{SnSEt}$ $(131.7 \mathrm{mg}, 0.38 \mathrm{mmol})$ in propionitrile $(1.0 \mathrm{~mL})$ was added. After the mixture was stirred for $13 \mathrm{~h}$ at room temperature, it was quenched with sat. aq. $\mathrm{NaHCO}_{3}(10 \mathrm{~mL})$, and the whole mixture was extracted with ethyl acetate $(5 \mathrm{~mL} \times 3)$. The combined extracts were washed with brine $(5 \mathrm{~mL} \times 2)$, dried over anhydrous $\mathrm{Na}_{2} \mathrm{SO}_{4}$, and concentrated in vacuo. The crude product was purified on silica gel TLC ( $n$ hexane : ethyl acetate $=6: 1$ ) to give the title compound $\mathbf{8 b}$.

Yield 79\% (41.7 mg); yellow oil; $R_{\mathrm{f}}=0.4$ ( $n$ hexane : ethyl acetate $=6: 1) ;{ }^{1} \mathrm{H} \mathrm{NMR}\left(400 \mathrm{MHz}, \mathrm{CDCl}_{3}\right) \delta 1.16(\mathrm{t}, J=7.5 \mathrm{~Hz}$, $3 \mathrm{H}), 1.20(\mathrm{t}, J=7.3 \mathrm{~Hz}, 3 \mathrm{H}), 1.23(\mathrm{t}, J=7.2 \mathrm{~Hz}, 3 \mathrm{H}), 2.27(\mathrm{q}, J=$ $7.3 \mathrm{~Hz}, 2 \mathrm{H}), 2.40$ (dt, $J=7.5,7.5 \mathrm{~Hz}, 2 \mathrm{H}), 2.53(\mathrm{t}, J=7.5 \mathrm{~Hz}, 2 \mathrm{H})$, $2.82(\mathrm{q}, J=7.5 \mathrm{~Hz}, 2 \mathrm{H}), 3.48(\mathrm{q}, J=7.2 \mathrm{~Hz}, 2 \mathrm{H}), 3.73(\mathrm{~s}, 3 \mathrm{H})$, 6.62-6.67 (m, 2H), $6.73(\mathrm{t}, J=7.5 \mathrm{~Hz}, 1 \mathrm{H}), 6.77-6.81(\mathrm{~m}, 3 \mathrm{H}) ;{ }^{13} \mathrm{C}$ NMR (100 MHz, $\left.\mathrm{CDCl}_{3}\right) \delta 11.7,14.3,14.7,24.0,26.5,28.0,31.4$, $46.8,55.5,114.4,118.6,129.5,142.1,145.6,153.5,194.2$; IR (neat) 2930, 1712, 1645, 1510, 1247, 1029, 833, 741, 691, $536 \mathrm{~cm}^{-1}$; HRMS (EI) calcd for $\mathrm{C}_{18} \mathrm{H}_{27} \mathrm{NO}_{2} \mathrm{~S}_{2}(\mathrm{M})^{+}$353.1483, found 353.1479 .

\section{Synthesis of ethyl (E)-2-[ethyl(4-methoxyphenyl)amino]-5- (phenylthio)pent-2-enethioate 8c}

In a $30 \mathrm{~mL}$ two-necked round-bottomed flask equipped with a magnetic stirring bar, a rubber septum, and an argon balloon were placed ethyl 2-cyclopropyl[(4-methoxyphenyl)imino] acetate $1 \mathrm{~b}(37.1 \mathrm{mg}, 0.150 \mathrm{mmol})$ and BPO (0.150 mmol, 36.3 $\mathrm{mg})$ in propionitrile $(5.0 \mathrm{~mL})$ at $-50{ }^{\circ} \mathrm{C}$. To it was added $\mathrm{EtAlCl}_{2}$ (0.14 mL, $0.150 \mathrm{mmol}, 1.07 \mathrm{M}$ in $n$ hexane), $\mathrm{Et}_{2} \mathrm{AlCl}(0.14 \mathrm{~mL}$, $0.150 \mathrm{mmol}, 1.07 \mathrm{M}$ in $n$ hexane), and TMSSPh (0.029 mL, 0.15 $\mathrm{mmol}$ ). After the mixture was stirred for $22 \mathrm{~h}$ at room temperature, it was quenched with sat. aq. $\mathrm{NaHCO}_{3}(10 \mathrm{~mL})$, and the whole mixture was extracted with ethyl acetate $(5 \mathrm{~mL} \times 3)$. The combined extracts were washed with brine $(5 \mathrm{~mL} \times 2)$, dried over anhydrous $\mathrm{Na}_{2} \mathrm{SO}_{4}$, and concentrated in vacuo. The crude product was purified on silica gel TLC ( $n$ hexane $:$ ethyl acetate $=$ $6: 1)$ to give the title compound $8 \mathbf{c}$.

Yield 53\% (30.8 mg); yellow oil; $R_{\mathrm{f}}=0.4$ (nhexane : ethyl acetate $=6: 1) ;{ }^{1} \mathrm{H}$ NMR $\left(400 \mathrm{MHz}, \mathrm{CDCl}_{3}\right) \delta 1.13(\mathrm{t}, 3 \mathrm{H}, J=7.3$ $\mathrm{Hz}), 1.17(\mathrm{t}, 3 \mathrm{H}, J=7.1 \mathrm{~Hz}), 2.51(\mathrm{q}, 2 \mathrm{H}, J=7.3 \mathrm{~Hz}), 2.96(\mathrm{t}, 2 \mathrm{H}, J$ $=7.3 \mathrm{~Hz}), 3.38(\mathrm{dt}, 2 \mathrm{H}, J=7.1,7.3 \mathrm{~Hz}), 3.73(\mathrm{~s}, 3 \mathrm{H}), 4.12(\mathrm{q}, 2 \mathrm{H}, J$ $=7.1 \mathrm{~Hz}), 6.56-6.60(\mathrm{~m}, 2 \mathrm{H}), 6.74-6.79(\mathrm{~m}, 2 \mathrm{H}), 6.87(\mathrm{t}, 1 \mathrm{H}, J=$ $7.1 \mathrm{~Hz}), 7.13-7.18(\mathrm{~m}, 1 \mathrm{H}), 7.21-7.29(\mathrm{~m}, 4 \mathrm{H}) ;{ }^{13} \mathrm{C}$ NMR $(100$ $\left.\mathrm{MHz}, \mathrm{CDCl}_{3}\right) \delta 13.2,14.1,27.8,32.1,45.3,55.6,60.8,114.3$, $114.6,126.1,128.9,129.0,129.3$, 136.2, 139.0, 141.7, 152.0, 165.8; IR (neat) 2975, 2360, 1715, 1509, 1241, 1180, 1040, 818, $739,690,535,510 \mathrm{~cm}^{-1}$; HRMS (EI) calcd for $\mathrm{C}_{22} \mathrm{H}_{27} \mathrm{NO}_{3} \mathrm{~S}(\mathrm{M})^{+}$ 385.1712 , found 385.1719 .

Synthesis of $S$-ethyl (E)-2-[ethyl(4-methoxyphenyl)amino]-5(phenylthio)pent-2-enethioate 8a using ethyl Grignard reagent

In a $30 \mathrm{~mL}$ two-necked round-bottomed flask equipped with a magnetic stirring bar, a rubber septum, and an argon balloon was placed $S$-ethyl 2-cyclopropyl-2-[(4-methoxyphenyl)imino] ethanethioate 1a $(39.5 \mathrm{mg}, 0.150 \mathrm{mmol})$ in propionitrile $(0.5$ $\mathrm{mL})$ at $-50{ }^{\circ} \mathrm{C}$. To it was added EtMgBr $(0.27 \mathrm{~mL}, 0.300 \mathrm{mmol}$, 1.10 $\mathrm{M}$ in THF). After the mixture was stirred for $10 \mathrm{~min}$ at room temperature, a solution of NCS $(22.0 \mathrm{mg}, 0.15 \mathrm{mmol})$ in propionitrile $(0.75 \mathrm{~mL})$ was added. The mixture was stirred for $10 \mathrm{~min}$ at room temperature, and a solution of $n \mathrm{Bu}_{3} \mathrm{SnSPh}$ $(119.7 \mathrm{mg}, 0.30 \mathrm{mmol})$ in propionitrile $(1.0 \mathrm{~mL})$ was added. After 
the mixture was stirred for $12 \mathrm{~h}$ at room temperature, it was quenched with sat. aq. $\mathrm{NaHCO}_{3}(10 \mathrm{~mL})$, and the whole mixture was extracted with ethyl acetate $(5 \mathrm{~mL} \times 3)$. The combined extracts were washed with brine $(5 \mathrm{~mL} \times 2)$, dried over anhydrous $\mathrm{Na}_{2} \mathrm{SO}_{4}$, and concentrated in vacuo. The crude product was purified on silica gel TLC ( $n$ hexane : ethyl acetate $=6: 1$ ) to give the title compound $\mathbf{8 a}(12.7 \mathrm{mg}, 21 \%$ yield).

\section{Synthesis of ethyl (E)-2-[ethyl(4-methoxyphenyl)amino]-5- (phenylthio)pent-2-enethioate $8 \mathrm{c}$ using ethyl Grignard reagent}

In a $30 \mathrm{~mL}$ two-necked round-bottomed flask equipped with a magnetic stirring bar, a rubber septum, and an argon balloon was placed ethyl 2-cyclopropyl[(4-methoxyphenyl)imino]acetate 1b $(37.1 \mathrm{mg}, 0.150 \mathrm{mmol})$ in propionitrile $(0.5 \mathrm{~mL})$ at $-50{ }^{\circ} \mathrm{C}$. To it was added EtMgBr $(0.27 \mathrm{~mL}, 0.300 \mathrm{mmol}, 1.10 \mathrm{M}$ in THF). After the mixture was stirred for $10 \mathrm{~min}$ at room temperature, a solution of NCS $(22.0 \mathrm{mg}, 0.15 \mathrm{mmol})$ in propionitrile $(0.75$ $\mathrm{mL}$ ) was added. The mixture was stirred for $10 \mathrm{~min}$ at room temperature, and a solution of $n \mathrm{Bu}_{3} \mathrm{SnSPh}(119.7 \mathrm{mg}, 0.30$ $\mathrm{mmol})$ in propionitrile $(1.0 \mathrm{~mL})$ was added. After the mixture was stirred for $12 \mathrm{~h}$ at room temperature, it was quenched with sat. aq. $\mathrm{NaHCO}_{3}(10 \mathrm{~mL})$, and the whole mixture was extracted with ethyl acetate $(5 \mathrm{~mL} \times 3)$. The combined extracts were washed with brine $(5 \mathrm{~mL} \times 2)$, dried over anhydrous $\mathrm{Na}_{2} \mathrm{SO}_{4}$, and concentrated in vacuo. The crude product was purified on silica gel TLC (nhexane : ethyl acetate $=6: 1$ ) to give the title compound $8 \mathrm{c}$ (9.3 $\mathrm{mg}, 16 \%$ yield).

\section{Synthesis of $S$-ethyl 2-cyano-2-cyclopropyl-2-[ethyl(4- methoxyphenyl)amino]ethanethioate 7 using ethyl Grignard reagent}

In a $30 \mathrm{~mL}$ two-necked round-bottomed flask equipped with a magnetic stirring bar, a rubber septum, and an argon balloon was placed $S$-ethyl 2-cyclopropyl-2-[(4-methoxyphenyl)imino] ethanethioate $1 \mathrm{a}(39.5 \mathrm{mg}, 0.150 \mathrm{mmol})$ in propionitrile $(0.5$ $\mathrm{mL})$ at $-50{ }^{\circ} \mathrm{C}$. To it was added EtMgBr $(0.27 \mathrm{~mL}, 0.300 \mathrm{mmol}$, $1.10 \mathrm{M}$ in THF). After the mixture was stirred for $10 \mathrm{~min}$ at room temperature, a solution of NCS $(22.0 \mathrm{mg}, 0.15 \mathrm{mmol})$ in propionitrile $(0.75 \mathrm{~mL})$ was added. The mixture was stirred for $10 \mathrm{~min}$ at room temperature, and TMSCN $(0.04 \mathrm{~mL} 0.30 \mathrm{mmol})$ was added. After the mixture was stirred for $23 \mathrm{~h}$ at room temperature, it was quenched with sat. aq. $\mathrm{NaHCO}_{3}(10 \mathrm{~mL})$, and the whole mixture was extracted with ethyl acetate $(5 \mathrm{~mL} \times$ $3)$. The combined extracts were washed with brine $(5 \mathrm{~mL} \times 2)$, dried over anhydrous $\mathrm{Na}_{2} \mathrm{SO}_{4}$, and concentrated in vacuo. The crude product was purified on silica gel TLC (nhexane : ethyl acetate $=6: 1)$ to give the title compound $7(15.8 \mathrm{mg}$. $33 \%$ yield).

\section{Synthesis of $S$-ethyl (E)-5-chloro-2-[ethyl(4-methoxyphenyl) amino]pent-2-enethioate 9}

In a $30 \mathrm{~mL}$ two-necked round-bottomed flask equipped with a magnetic stirring bar, a rubber septum, and an argon balloon was placed $S$-ethyl 2-cyclopropyl-2-[(4-methoxyphenyl)imino] ethanethioate 1a $(39.5 \mathrm{mg}, 0.150 \mathrm{mmol})$ in propionitrile $(0.5$ $\mathrm{mL})$ at $-50{ }^{\circ} \mathrm{C}$. To it was added $\mathrm{Et}_{2} \mathrm{AlCl}(0.27 \mathrm{~mL}, 0.286 \mathrm{mmol}$,
$1.05 \mathrm{M}$ in $n$ hexane). After the mixture was stirred for $30 \mathrm{~min}$ at room temperature, a solution of NCS $(22.0 \mathrm{mg}, 0.15 \mathrm{mmol})$ in propionitrile $(0.75 \mathrm{~mL})$ and $\mathrm{Ti}(\mathrm{OEt})_{4}(0.063 \mathrm{~mL} 0.30 \mathrm{mmol})$ were added successively. The mixture was stirred for $72 \mathrm{~h}$ at room temperature and then quenched with sat. aq. $\mathrm{NaHCO}_{3}(10 \mathrm{~mL})$. The whole mixture was extracted with ethyl acetate $(5 \mathrm{~mL} \times 3)$. The combined extracts were washed with brine $(5 \mathrm{~mL} \times 2)$, dried over anhydrous $\mathrm{Na}_{2} \mathrm{SO}_{4}$, and concentrated in vacuo. The crude product was purified on silica gel TLC (nhexane : ethyl acetate $=6: 1$ ) to give the title compound 9 .

Yield 55\% (27.0 mg); yellow oil; $R_{\mathrm{f}}=0.4$ ( $n$ hexane : ethyl acetate $=6: 1) ;{ }^{1} \mathrm{H} \mathrm{NMR}\left(400 \mathrm{MHz}, \mathrm{CDCl}_{3}\right) \delta 1.22(\mathrm{t}, J=7.3 \mathrm{~Hz}$, $3 \mathrm{H}), 1.24(\mathrm{t}, J=7.1 \mathrm{~Hz}, 3 \mathrm{H}), 2.46(\mathrm{dt}, J=6.9,6.9 \mathrm{~Hz}, 2 \mathrm{H}), 2.84(\mathrm{q}$, $J=7.3 \mathrm{~Hz}, 2 \mathrm{H}), 3.48(\mathrm{q}, J=7.1 \mathrm{~Hz}, 2 \mathrm{H}), 3.52(\mathrm{t}, J=6.9 \mathrm{~Hz}, 2 \mathrm{H})$, $3.75(\mathrm{~s}, 3 \mathrm{H}), 6.63-6.67(\mathrm{~m}, 2 \mathrm{H}), 6.72(\mathrm{t}, J=6.9 \mathrm{~Hz}, 1 \mathrm{H}), 6.78-6.82$ $(\mathrm{m}, 2 \mathrm{H}) ;{ }^{13} \mathrm{C} \mathrm{NMR}\left(100 \mathrm{MHz}, \mathrm{CDCl}_{3}\right) \delta 13.0,14.3,23.8,31.1,42.4$, $45.5,55.6,114.3,114.8,132.4,140.6,143.0,152.3$, 193.8; IR (neat) 2967, 2932, 2470, 1673, 1512, 1456, 1250, 1031, 835, 753, $560,513 \mathrm{~cm}^{-1}$; HRMS (EI) calcd for $\mathrm{C}_{16} \mathrm{H}_{22} \mathrm{ClNO}_{2} \mathrm{~S}(\mathrm{M})^{+}$ 327.1060 , found 327.1056 .

\section{Ethyl 2-cyclopropyl-2-[ethyl(4-methoxyphenyl)amino]-4- pentenoate 10}

Under an argon atmosphere, to a propionitrile $(0.5 \mathrm{~mL})$ solution of ethyl 2-cyclopropyl-2-[(4-methoxyphenyl)imino]acetate $\mathbf{1 b}$ (41.6 $\mathrm{mg}, 0.150 \mathrm{mmol}$ ) and benzoyl peroxide (36.3 $\mathrm{mg}, 0.150$ $\mathrm{mmol})$ were added diethylaluminum chloride $(0.158 \mathrm{~mL}$, $0.150 \mathrm{mmol}, 0.95 \mathrm{M}$ in $n$ hexane), ethylaluminum dichloride ( $0.167 \mathrm{~mL}, 0.150 \mathrm{mmol}, 0.90 \mathrm{M}$ in $n$ hexane) and allyltributyltin $(0.094 \mathrm{~mL}, 0.300 \mathrm{mmol})$ at $-20{ }^{\circ} \mathrm{C}$. The reaction mixture was allowed to warm to ambient temperature with stirring for $8 \mathrm{~h}$. After the addition of $10 \%$ aq. $\mathrm{Na}_{2} \mathrm{SO}_{3}(5 \mathrm{~mL})$ and subsequently sat. aq. KF ( $5 \mathrm{~mL})$, the whole mixture was extracted with ethyl acetate $(10 \mathrm{~mL} \times 3)$. The combined extracts were washed with brine, dried over anhydrous $\mathrm{Na}_{2} \mathrm{SO}_{4}$ and concentrated in vacuo. The crude product was purified by preparative TLC on silica gel to give the title compound $\mathbf{1 0}$.

Yield 50\% (15.9 mg); yellow oil; $R_{\mathrm{f}}=0.3$ (nhexane : ethyl acetate $=6: 1) ;{ }^{1} \mathrm{H}$ NMR $\left(400 \mathrm{MHz}, \mathrm{CDCl}_{3}\right) \delta 0.27-0.40(\mathrm{~m}, 3 \mathrm{H})$, 0.43-0.49 (m, 1H), $0.85(\mathrm{t}, 3 \mathrm{H}, J=7.0 \mathrm{~Hz}), 1.07-1.13(\mathrm{~m}, 1 \mathrm{H})$, $1.31(\mathrm{t}, 3 \mathrm{H}, J=7.3 \mathrm{~Hz}), 2.35(\mathrm{dd}, 1 \mathrm{H}, J=7.9,14.0 \mathrm{~Hz}), 2.43(\mathrm{dd}$, $1 \mathrm{H}, J=6.1,14.0 \mathrm{~Hz}), 3.04(\mathrm{dq}, 1 \mathrm{H}, J=7.0,13.8 \mathrm{~Hz}), 3.20(\mathrm{dq}, 1 \mathrm{H}$, $J=7.0,13.8 \mathrm{~Hz}$ ), 3.78 (s, 3H), 4.18 (q, 2H, $J=7.3 \mathrm{~Hz}), 5.02-5.05$ $(\mathrm{m}, 2 \mathrm{H}), 5.91-5.99(\mathrm{~m}, 1 \mathrm{H}), 6.76-6.79(\mathrm{~m}, 2 \mathrm{H}), 7.14-7.17(\mathrm{~m}$, $2 \mathrm{H}) ;{ }^{13} \mathrm{C}$ NMR $\left(100 \mathrm{MHz}, \mathrm{CDCl}_{3}\right) \delta 2.8,3.3,14.4,14.8,17.1,41.6$, 45.0, 55.3, 60.3, 69.8, 113.1, 117.2, 130.4, 134.9, 140.0, 156.6, 174.1; IR (neat) 2950, 1735, 1515, 1220, 1045, 920, $840 \mathrm{~cm}^{-1}$; HRMS (EI) calcd for $\mathrm{C}_{19} \mathrm{H}_{27} \mathrm{NO}_{3}(\mathrm{M})^{+}$317.1991, found 317.1999.

\section{Ethyl 2-cyclopropyl-2-[(4-methoxyphenyl)amino]-4-pentenoate}

11

Bis(trimethylsilyl)aluminum chloride was prepared by mixing aluminum chloride (13.4 $\mathrm{mg}, 0.100 \mathrm{mmol})$ and tris(trimethylsilyl)aluminum $(0.385 \mathrm{~mL}, 0.200 \mathrm{mmol})$ from $0{ }^{\circ} \mathrm{C}$ to ambient temperature under an argon atmosphere. Under an argon atmosphere, to a propionitrile $(0.5 \mathrm{~mL})$ solution of ethyl 
2-cycloprpyl-2-[(4-methoxyphenyl)imino]acetate $\mathbf{1 b}(39.5 \mathrm{mg}$, $0.150 \mathrm{mmol}$ ) and benzoyl peroxide $(54.5 \mathrm{mg}, 0.225 \mathrm{mmol})$ were added bis(trimethylsilyl)aluminum chloride $(0.300 \mathrm{mmol})$ prepared as above and allyltributyltin $(0.094 \mathrm{~mL}, 0.300 \mathrm{mmol})$ at $-20{ }^{\circ} \mathrm{C}$. The reaction mixture was allowed to warm to ambient temperature and heated at $50{ }^{\circ} \mathrm{C}$ with stirring for $23 \mathrm{~h}$. After the addition of $10 \%$ aq. $\mathrm{Na}_{2} \mathrm{SO}_{3}(5 \mathrm{~mL})$ and subsequently sat. aq. $\mathrm{KF}$ $(5 \mathrm{~mL})$, the whole mixture was extracted with ethyl acetate $(10 \mathrm{~mL} \times 3)$. The combined extracts were washed with brine, dried over anhydrous $\mathrm{Na}_{2} \mathrm{SO}_{4}$ and concentrated in vacuo. The crude product was purified by preparative TLC on silica gel to give the title compound $\mathbf{1 1 .}$

Yield $58 \%$ (25.2 mg); yellow oil; $R_{\mathrm{f}}=0.25$ ( $n$ hexane : ethyl acetate $=6: 1) ;{ }^{1} \mathrm{H}$ NMR $\left(400 \mathrm{MHz}, \mathrm{CDCl}_{3}\right) \delta 0.36-0.60(\mathrm{~m}, 4 \mathrm{H})$, $1.20(\mathrm{t}, 3 \mathrm{H}, J=7.3 \mathrm{~Hz}), 1.24-1.34(\mathrm{~m}, 1 \mathrm{H}), 2.69(\mathrm{dd}, 1 \mathrm{H}, J=7.3$, $14.2 \mathrm{~Hz}$ ), 2.82 (dd, $1 \mathrm{H}, J=7.6,14.0 \mathrm{~Hz}$ ), 3.73 (s, 3H), 4.08 (br, $1 \mathrm{H}), 4.15$ (q, $2 \mathrm{H}, J=7.3 \mathrm{~Hz}), 5.00-5.07(\mathrm{~m}, 2 \mathrm{H}), 5.65-5.80(\mathrm{~m}$, 1H), 6.64-6.74 (m, 4H); ${ }^{13} \mathrm{C}$ NMR (100 MHz, $\left.\mathrm{CDCl}_{3}\right) \delta 2.9,3.1$, 14.2, 18.0, 40.2 , 55.6, 61.2, 64.1, 114.2, 117.9, 118.6, 133.1, 139.4, 152.7, 174.2; IR (neat) 3380, 2980, 1740, 1520, 1245, 1190, 1050, 925, $830 \mathrm{~cm}^{-1}$; HRMS (EI) calcd for $\mathrm{C}_{17} \mathrm{H}_{23} \mathrm{NO}_{3}(\mathrm{M})^{+}$289.1678, found 289.1691 .

\section{Conflicts of interest}

There are no conflicts to declare.

\section{Acknowledgements}

This work was supported by Grants-in-Aid for Scientific Research (B) and on Innovative Areas "Organic Synthesis Based on Reaction Integration. Development of New Methods and Creation of New Substances" from JSPS and MEXT.

\section{Notes and references}

1 For selected reviews, see: (a) L. A. Paquette, Chem. Rev., 1986, 86, 733-750; (b) J. Salaun, Chem. Rev., 1989, 89, 1247-1270; (c) H. N. C. Wong, M. Y. Hon, C. W. Tse, Y. C. Yip, J. Tanko and T. Hudlicky, Chem. Rev., 1989, 89, 165-198; (d) O. G. Kulinkovich, Chem. Rev., 2003, 103, 2597-2632; (e) H. Lebel, J.-F. Marcoux, C. Molinaro and A. B. Charette, Chem. Rev., 2003, 103, 977-1050; (f) M. Rubin, M. Rubina and V. Gevorgyan, Chem. Rev., 2007, 107, 3117-3179; $(g)$ H. Pellissier, Tetrahedron, 2008, 64, 7041-7095; (h) C. A. Carson and M. A. Kerr, Chem. Soc. Rev., 2009, 38, 3051-3060; (i) D. Y. K. Chen, R. H. Pouwer and J.-A. Richard, Chem. Soc. Rev., 2012, 41, 4631-4642; (j) P. Tang and Y. Qin, Synthesis, 2012, 44, 2969-2984; $(k)$ M. A. Cavitt, L. H. Phun and S. France, Chem. Soc. Rev., 2014, 43, 804-818; (l) H. K. Grover, M. R. Emmett and M. A. Kerr, Org. Biomol. Chem., 2015, 13, 655-671; $(\mathrm{m})$ C. Ebner and E. M. Carreira, Chem. Rev., 2017, 117, 1165111679; (n) W. Wu, Z. Lin and H. Jiang, Org. Biomol. Chem., 2018, 16, 7315-7329; (o) A. J. Craig and B. C. Hawkins, Synthesis, 2020, 52, 27-39.
2 (a) E. P. Kohler and J. B. Conant, J. Am. Chem. Soc., 1917, 39, 1404-1420; (b) G. Daviaud and P. Miginiac, Tetrahedron Lett., 1972, 13, 997-1000; (c) D. Tunemoto, N. Araki and K. Kondo, Tetrahedron Lett., 1977, 18, 109-112; (d) I. Böhm, R. Schulz and H.-U. Reissig, Tetrahedron Lett., 1982, 23, 2013-2016; (e) H. H. Wasserman and R. P. Dion, Tetrahedron Lett., 1982, 23, 1413-1416; $(f)$ S. Ogoshi, M. Nagata and H. Kurosawa, J. Am. Chem. Soc., 2006, 128, 5350-5351; $(g)$ L. Liu and J. Montgomery, J. Am. Chem. Soc., 2006, 128, 5348-5349; $(h)$ M. S. Anstey, C. M. Yung, J. Du and R. G. Bergman, J. Am. Chem. Soc., 2007, 129, 776-777; (i) T. Ok, A. Jeon, J. Lee, J. H. Lim, C. S. Hong and H. S. Lee, J. Org. Chem., 2007, 72, 7390-7393; (j) K. Wang, D. Xiang, J. Liu, W. Pan and D. Dong, Org. Lett., 2008, 10, 1691-1694; (k) Y. Sumida, H. Yorimithu and K. Oshima, J. Org. Chem., 2009, 74, 3196-3198; (l) Q. Li, G. Jing, L. Jiao and Z. Yu, Org. Lett., 2010, 12, 1332-1335; (m) C. Sparr and R. Gilmour, Angew. Chem., Int. Ed., 2011, 50, 8391-8395; (n) H. K. Grover, T. P. Lebold and M. A. Kerr, Org. Lett., 2011, 13, 220-223; (o) W. Qi, P. Wang, L. Fan and S. Zhang, J. Org. Chem., 2013, 78, 5918-5924; (p) M. Li, S. Lin, Z. Dong, X. Zhang, F. Liang and J. Zhang, Org. Lett., 2013, 15, 39783981; (q) P. Kumar, R. Dey and P. Banerjee, Org. Lett., 2018, 20, 5163-5166.

3 For $N$-alkylation to $\alpha$-iminoesters found in our laboratories, see: (a) Y. Niwa, K. Takayama and M. Shimizu, Bull. Chem. Soc. Jpn., 2002, 75, 1819-1825; (b) Y. Niwa and M. Shimizu, J. Am. Chem. Soc., 2003, 125, 3720-3721; (c) M. Shimizu, H. Itou and M. Miura, J. Am. Chem. Soc., 2005, 127, 32963297; (d) I. Mizota and M. Shimizu, Chem. Rec., 2016, 16, 688-702; (e) I. Mizota, C. Ueda, Y. Tesong, Y. Tsujimoto and M. Shimizu, Org. Lett., 2018, 20, 2291-2296; $(f)$ I. Mizota, Y. Tadano, Y. Nakamura, T. Haramiishi, M. Hotta and M. Shimizu, Org. Lett., 2019, 21, 2663-2667; (g) M. Shimizu, H. Imazato, I. Mizota and Y. Zhu, RSC Adv., 2019, 9, 17341-17346; (h) M. Shimizu, M. Mushika, I. Mizota and Y. Zhu, RSC Adv., 2019, 9, 23400-23407; $(i)$ M. Shimizu, Y. Furukawa, I. Mizota and Y. Zhu, New J. Chem., 2020, 44, 152-161.

4 (a) I. Mizota, Y. Matsuda, S. Kamimura, H. Tanaka and M. Shimizu, Org. Lett., 2013, 15, 4206-4209; (b) H. Tanaka, I. Mizota and M. Shimizu, Org. Lett., 2014, 16, 2276-2279; (c) K. Nakahama, M. Suzuki, M. Ozako, I. Mizota and M. Shimizu, Asian J. Org. Chem., 2018, 7, 910-913.

5 I. Mizota, Y. Nakajima, A. Higashino and M. Shimizu, Arabian J. Sci. Eng., 2017, 42, 4249-4261. Also see, ref. 3b and $3 e$.

6 To clarify the exact origin of the reactivity of thioesters, computational study was carried out using the Gaussian 03 program. After the structural optimization, we found that the LUMO energy of the thioester was lower than that of the normal ester. We also found that the frontier electron density of the thioester was higher than that of the normal ester, leading to the increased reactivity of the nitrogen atom of the thioester. These computational analyses support the experimental results. Details of these studies have already been communicated. ${ }^{3 e}$ 
7 P. Perlmutter, Conjugated Addition Reactions in Organic Synthesis, Pergamon, Oxford, 1992.

8 W. C. Groutas, L. B. Krasnova and A. K. Yudin, Phenylthiotrimethylsilane, in e-EROS Encyclopedia of Reagents for Organic Synthesis, 2008, DOI: 10.1002/ 047084289x.rp132.pub2.

9 C. G. Gutierrez and L. R. Summerhays, J. Org. Chem., 1984, 49, 5206-5213.

10 (a) L. Rçsch, G. Altnau and W. H. Otto, Angew. Chem., Int. Ed., 1981, 20, 581-582; (b) M. A. Avery, W. K. M. Chong and C. Jennings-White, J. Am. Chem. Soc., 1992, 114, 974-979.
11 (a) R. C. Hartley, I. C. Richards and S. Warren, J. Chem. Soc., Perkin Trans. 1, 1995, 359-376; (b) A. N. Matukonis, J. D. Musselman and T. A. Tiley, Tetrahedron Lett., 2002, 43, 7031-7034; (c) M. M. Coulter, K. G. M. Kou, B. Galligan and V. M. Dong, J. Am. Chem. Soc., 2010, 132, 16330-16333; (d) X.-H. Yang, R. T. Davison, S.-Z. Nie, F. A. Cruz, T. M. McGinnis and V. M. Dong, J. Am. Chem. Soc., 2019, 141, 3006-3013. 